\title{
Device model for training of laparoscopic surgical skills
}

\section{Modelo de dispositivo para treinamento de habilidades operatórias em laparoscopia}

\author{
Renan Silva Couto'; Andrea da Costa Veloso'; Fatima Gurgel Antunes'; Renato Ferrari²; Rhycktielle Gladysman Ferrer Carneiro²
}

\section{A B S T R A C T}

The authors present a especially constructed, lightweight, collapsible, portable and low cost model device for skills training in laparoscopic.

Key words: Education, Medical. Training/education. Teaching Materials.

\section{INTRODUCTION}

$\mathrm{T}$ he surgeon's skill is fundamentally acquired through continuous practice. The knowledge and the proper training of the surgical technique cannot only improve the experience but also avoid complications in surgical procedures ${ }^{1}$.

Despite new surgical techniques such as laparoscopy and robotic surgery, which are important milestones in the history of medicine and surgery, the critical surgical times - dieresis, hemostasis and synthesis - remain unchanged and need to be taught ${ }^{2,3}$. However, despite the existence of non-organic models, such as virtual simulators and black boxes, these resources are not available to most physicians, training traditionally following an apprenticeshipbased model in the operating room, an approach that can be time consuming, costly 4,5 and unethical due to the potential harm to the patient resulting from the training surgeon's inexperience ${ }^{6}$.

Moreover, the Brazilian surgery training centers, mostly institutions of the public health system, lack funds for investment in educational technologies.

Therefore, based on the importance of surgical technique practical learning, and to facilitate the initial training in developing laparoscopy skills, we created a device model.

\section{DESCRIPTION OF THE DEVICE}

This is a device for simulating situations similar to those found in surgery, such as gripping structures, dissection, ligatures and tissues suturing.
The model was built in white acrylic and consists of three faces: front face (1), left lateral face (2) and right lateral face (3), all put together by a set nuts and bolts (4) for ease of transport and portability (Figure 1). All faces have holes (5) for the passage of laparoscopic instruments (Figure 1).

On the front side there are a rectangular opening (6) and a perpendicular support (7) for accommodating tablets and the like, to capture images and indirect

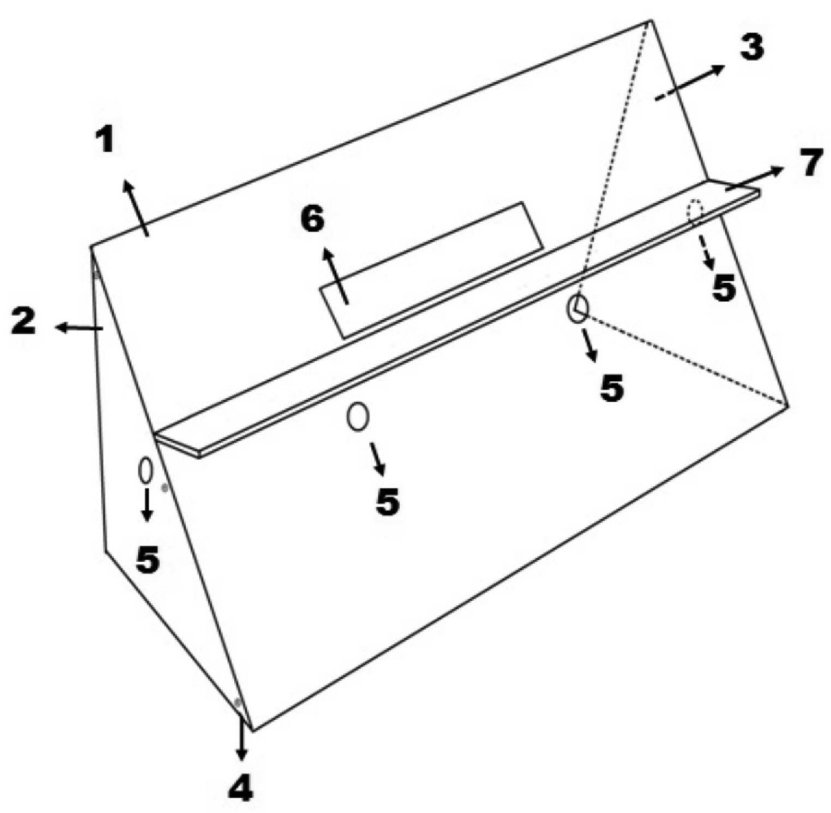

Figure 1 - Training model of laparoscopic skills in perspective.

1. Serviço de Coloproctologia do Hospital Naval Marcílio Dias (HNMD), Rio de Janeiro-RJ, Brasil; 2. Instituto de Ginecologia da Universidade Federal do Rio de Janeiro (UFRJ), Rio de Janeiro-RJ, Brasil. 
visualization of the movements by the practitioner, as occurs in real surgical procedures (Figure 2).

\section{DISCUSSION}

The black boxes traditionally known consist of closed or half open containers of wood or plastic, with holes for insertion of instruments and fixed or mobile micro cameras for visual control of the tasks performed with the instruments ${ }^{7}$.

Although there are other inexpensive devices as an alternative to more sophisticated simulators used in large training centers ${ }^{8-11}$, we believe such devices have some limitations: they are usually made as heavy containers with large size, rendering transport and mobility difficult; they often require an interior light source, generated by another device or an external light nearby, hampering portability; furthermore, in most cases they require the use of trocars for manipulation of laparoscopic instruments.

Aimed at solving these limitations, we developed the model. Despite lacking its own lighting apparatuses, it requires no exclusive light sources for use, only needing ambient lighting. The traditionally used microcamera follows as an alternative however, it was essentially replaced by the camera of tablets, mobile phones and the like, which, aided by free applications available, even allow one to wirelessly send the images captured in real time to monitors or TV sets, further contributing to the portability and providing vision similar to the actual procedure. As for the holes for insertion of laparoscopic forceps, we found an excellent correlation in their dimensions, capable of avoiding the variation of unwanted linear motion of the instruments shaft caused by the lack of a fixed support point in large holes in relation to the diameter of the forceps and the

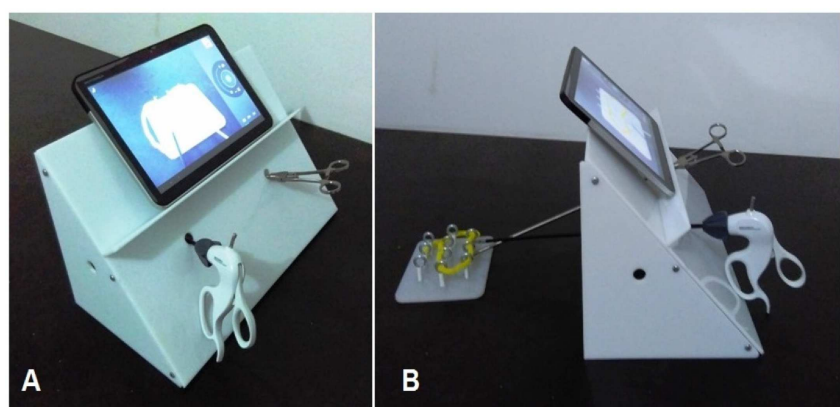

Figure 2 - Representation of the model for training of laparoscopic skills in use. A) model in perspective. B) model in profile.

very limited angular movement in just orifices in relation to the diameter of the instrument. Consequently, we avoided the need of rubber membranes and / or use of trocars, which increase production costs

The formation of a surgeon is complex, since it requires knowledge of the natural history of the disease, clinical diagnosis, additional exams, the choice of treatment and opportunity of its application, besides mastering the surgical technique to be employed to achieve the ultimate goal, the patient's healing ${ }^{12}$.

The creation of the presented model, of low production cost, showed a viable option for purchase by institutions and individuals, proving to be of great value to education and training for those interested in minimally invasive surgery.

\section{Acknowledgements}

We thank the Professor José Eduardo Ferreira Manso, for all the support and encouragement with invaluable contribution.

\title{
R E S U M O
}

\begin{abstract}
Os autores apresentam um modelo de dispositivo para treinamento de habilidades em laparoscopia de original construção, leve
\end{abstract} desmontável, portátil e de baixo custo.

Descritores: Educação Médica. Capacitação/educação. Materiais de Ensino.

\section{REFERENCES}

1. Townsend CM, Beauchamp RD, Evers BM, Mattox KL. Sabiston Tratado de Cirurgia: As bases biológicas da prática cirúrgica moderna. 18 ed. Rio de Janeiro: Elsevier; 2009.

2. Goffi FS, Tolosa EMC. Operações fundamentais. In: Goffi FS. Técnica cirúrgica: bases anatômicas e fisiopatológicas e técnicas de cirurgia. 4ª ed. São Paulo: Atheneu; 1996. p.52-3.

3. Ethicon $\mathrm{n} / \mathrm{d}$. Knot tying manual. New Jersey: Ethicon; 2005

4. Harrington DT, Roye GD, Ryder BA, Miner TJ, Richardson P, Cioffi WG. A time-cost analysis of teaching a laparoscopic enteroenterostomy. J Surg Educ. 2007;64(6):342-5.
5. Bridges $M$, Diamond $D L$. The financial impact of teaching surgical resident in the operating room. Am J Surg. 1999;177(1):28-32.

6. Kohn LT, Corrigan JM, Donaldson MS. To err is human: building a safer health system. Washington, DC: Institute of Medicine; 2000.

7. Undre S, Darzi A. Laparoscopy simulators. J Endourol. 2007;21(3):274-9.

8. Beatty JD. How to build an inexpensive laparoscopic webcambased trainer. BJU Int. 2005;96(4):679-82.

9. Batista EFN, Batista GAP. Treinamento em videocirurgia - atualização de modelo de "caixa preta" para uso com microcâmera. Rev Bras Videocir. 2006;4(1):21-5. 
10. Batista DM, Felzemburgh VA, Matos EP. New experimental model for training in videosurgery. Acta Cir Bras. 2012;27(10):741-5.

11. Martins JMP, Ribeiro RVP, Cavazzola LT. White box: caixa para treinamento laparoscópico de baixo custo. $A B C D$, arq bras cir dig. 2015;28(3):204-6.

12. Ebram Neto J, De Paula PR, Celano RMG, Hirose K, Cauduro AB, Speranzini MB. Modelo de dispositivo para treinamento e avaliação das habilidades em técnica operatória. Acta Cir Bras. 1998;13(1):58-60.
Received at: 07/07/2015

Accepted for publication: 09/08/2015

Conflict of interest: none.

Source of funding: none.

Mailing address:

Renato Ferrari

E-mail: renatoferrari@hucff.ufrj.br 